\title{
PERSPECTIVAS DA FELICIDADE
}

\author{
English title: PERSPECTIVES OF HAPPINESS
}

doi>10.33726/akdpapers2447-7656v11a72021p145-167

\section{CARVALHO, Isaar Soares de ${ }^{1}$}

RESUMO: O presente artigo examina as várias interpretações do tema da felicidade, postos sob uma perspectiva interdisciplinar, tanto em relação à sua presença na cultura em geral quanto na Filosofia, na Política, na Religião, na Literatura e na Música. Nosso principal objetivo é contribuir para o estudo de tema tão vasto e de caráter multidisciplinar. Metodologicamente, faz-se uma revisão bibliográfica em acervos físicos e digitais, partindo dos pressupostos inscritos nas várias formas de interpretação do conceito de felicidade, especialmente em relação às condições históricas e sociais da existência humana. Como resultados da pesquisa, vimos que a felicidade é um conceito amplo e encontrá-la plenamente é algo raro, visto que não pode ser interpretada literalmente, pois o que vai bem é relativo, parcial, e o conceito de totalidade é mais um ideal do que uma realidade.

PALAVRAS-CHAVE: Cultura, Filosofia, Ética, Felicidade

\begin{abstract}
This article examines the various interpretations of the theme of happiness, placed under an interdisciplinary perspective, both in relation to their presence in culture in general and in Philosophy, Politics, Religion, Literature and Music. Our main objective is to contribute to the study of such a vast and multidisciplinary topic. Methodologically, a bibliographic review is made in physical and digital collections, starting from the assumptions inscribed in the various forms of interpretation of the concept of happiness, especially in relation to the historical and social conditions of human existence. As a result of the research, we saw that happiness is a broad concept and finding it fully is rare, since it cannot be interpreted literally, because what goes well is relative, partial, and the concept of wholeness is more of an ideal than that a reality.
\end{abstract}

KEYWORDS: Culture, Philosophy, Ethics, Happiness

\footnotetext{
${ }^{1}$ Doutor em Filosofia (UNICAMP). Pós-Doutor em Letras (USP). Docente do Departamento de Ciências Humanas da UEMG - Unidade Frutal.
} 


\section{$\mathrm{AKED}$ 西A}

INTRODUÇÃO: A RELEVÂNCIA DO TEMA

A felicidade não pode se alimentar apenas de recordações do passado, necessita, também, dos sonhos do futuro (Jorge Amado) ${ }^{2}$.

$\mathrm{Na}$ área da Filosofia, o tema da felicidade é discutido historicamente desde a Antiguidade, por pensadores como Platão, Aristóteles, Epicuro, Agostinho, Hobbes, Rousseau, Montesquieu e vários outros, o que mostra a sua relevância na cultura ocidental.

Recentemente, o Prof. Franklin Leopoldo e Silva publicou uma obra introdutória sobre o tema, abordando de forma sintética a Felicidade, abarcando desde os Pré-Socráticos à Filosofia Contemporânea.

O tema da Felicidade tem sido objeto de um número considerável de publicações atualmente, bem como alvo da produção de filmes e novelas, sendo discutido tanto de forma direta quanto indireta na teledramaturgia, tendo, numa novela de Manoel Carlos, sido dedicada ao tema, intitulada propriamente de "Felicidade". Nela, se mostram os conflitos humanos em busca da Felicidade, numa sociedade marcada pela competição e pelo egoísmo. $\mathrm{Na}$ ambição de tal aquisição, se adotam até mesmo estratégias antiéticas, como o assédio moral e a violência, artimanhas adotadas para a conquista da pessoa desejada.

Essa novela foi um tipo de reedição, moralmente falando, das novelas "Vale Tudo" e "Por Amor", esta última também de Manoel Carlos. Em ambas, o realismo defendido por Maquiavel em relação à Política era adotado nas relações humanas, de tal modo que o título "Vale Tudo", por sua vez, foi bem apropriado, enquanto que o título "Felicidade", na prática, representa um ocultamento das verdadeiras relações de competição entre os homens e as mulheres, especialmente quando se trata desse controvertido conceito, visto que alguns se sentem felizes produzindo a infelicidade de outros.

Por outro lado, no cinema, tornou-se célebre o filme Em busca da Felicidade, protagonizado por Will Smith. Mostra-se nele que as diversas crises que atingem os membros de uma família advêm, não raro, das dificuldades próprias das relações conjugais, do desemprego, do problema da moradia, da

\footnotetext{
${ }^{2}$ JORGE AMADO. O Gato Malhado e a Andorinha Sinhá. 43. ed. Rio: Record, 2004, p. 53.
} 


\section{AKED霆}

alimentação e do acesso à saúde. No filme, também, dá-se grande ênfase à qualificação profissional, bem de alto valor numa sociedade altamente competitiva e que trocou o celeste porvir pelo sonho dogma do americano, mesmo que para isso acabasse por incentivar uma nova guerra de todos contra todos e, por consequência, encorpar o individualismo.

Em tal sociedade, onde a competição do estado de natureza foi renovada pela ética capitalista, a felicidade tem sido interpretada mais do ponto de vista da realização pessoal do que do bem-estar do corpo social. Partindo desses pressupostos, portanto, tratemos do tema.

\section{VOLTAIRE E A FELICIDADE COMO EXPERIÊNCIA TRANSITÓRIA}

No erudito Dictionnaire Philosophique (VOLTAIRE, 2021), explica-se que a Felicidade é algo temporário, passageiro, como o próprio termo "heurex", em Francês, a define. Voltaire explica que esse termo é derivado de "heur" (hora), de onde provêm as expressões como "em boa hora" ou "em má hora". Ele observa que as nações antigas admitiam haver horas ou tempos bons ou funestos.

Para Voltaire, aquilo que se chama de Felicidade "é uma ideia abstrata, composta de algumas ideias de prazer", observando que um momento de prazer não faz um homem feliz, nem um momento de dor o torna infeliz. $O$ sábio ainda afirma que "o prazer é mais rápido do que a Felicidade e a Felicidade do que a bem-aventurança". A prosperidade, no entanto, não garante necessariamente a Felicidade, pois dependendo da situação, uma pessoa próspera não pode desfrutar das delícias de um banquete preparado para ela, por que poderá estar com náuseas, e. $g$.

Nesse sentido, vale lembrar o célebre mito grego, que versa a respeito do Rei Midas, conhecido por sua ganância. Tendo tratado com civilidade a Sileno, que havia se perdido, Midas pediu ao deus Dioniso, como recompensa, que the concedesse o poder de transformar em ouro tudo aquilo que viesse a tocar. Seu pedido foi atendido, o que revelou o seu absurdo, pois como tudo o que ele tangia se transformava em ouro, ao tentar comer ele se deparou com o problema de que até sua refeição se transformava em ouro - o que o levaria à 


\section{AKED}

morte. Foi, então, que ele pediu a Dioniso que revertesse seu pedido insano, o que ilustra o fato de que o conceito de riqueza também é relativo.

No Brasil, confirmando o fato de que a riqueza não é garantia de bemestar e Felicidade, temos vários relatos a respeito de pessoas que, nos tempos da mineração, morreram com o ouro nas mãos. De acordo com Antonil, "sendo a terra que dá ouro esterilíssima de tudo o que se há mister para a vida humana, e não menos estéril a maior parte dos caminhos das minas, não se pode crer o que padeceram ao princípio os mineiros por falta de mantimentos"3.

A riqueza do ouro, em si mesma, por outro lado, não torna os homens felizes, melhores ou mais virtuosos. Nesse sentido, Antonil indaga, ironicamente: "Que maravilha, pois, que sendo o ouro tão formoso e tão precioso metal, tão útil para o comércio humano e tão digno de se empregar nos vasos e ornamentos dos templos para o culto divino, seja pela insaciável cobiça dos homens contínuo instrumento e causa de muitos danos?"4. De tal modo, que a Felicidade em relação à posse de bens é relativa, quer seja na Mitologia Grega, quer seja na Filosofia, na Religião ou na História, que lida com os fatos e suas narrativas, procurando eliminar destas os mitos e as ideologias, como um minerador que joga fora o cascalho para ficar com o metal precioso.

\section{A FELICIDADE COMO TEMA DA FILOSOFIA E DA POLÍTICA}

A Felicidade é vista na perspectiva social e política por Platão, que esperava que os governantes reconduzissem a cidade de Atenas da injustiça para a justiça. Na "Sétima Carta", Platão deixa claro que a paz civil depende da presença de homens justos na direção do Estado (Pólis).

Para Aristóteles, a vida feliz na Pólis seria possível, além da presença de homens justos em sua direção, da existência de uma classe média, o que evitaria as revoltas e garantiria a estabilidade política. Por outro lado, para Agostinho, a verdadeira Felicidade ou beatitude encontrar-se-ia na Cidade de Deus.

\footnotetext{
${ }^{3}$ Adriana Romeiro. Os sertões da fome: História trágica das minas de ouro em fins do século XVII. In: SÆculum - Revista de História [19]; João Pessoa, jul./dez. 2008, p. 176.

${ }^{4}$ Adriana Romeiro, idem, p. 177.
} 
Dante afirmava que o homem tem duas beatitudes: uma, a Felicidade, no âmbito civil, outra, a beatitude eterna, alcançando-se a primeira através da Filosofia e a segunda pelos ensinos de caráter espiritual que transcendem a razão.

Já Hobbes, contrasta a situação de miséria e infelicidade do homem no estado de natureza com a criação do Estado, que foi projetado para nossa paz e defesa. É digno de nota que um dos capítulos mais conhecidos do Leviatã, seja o de número XIII, intitulado: "Da condição natural da humanidade relativamente à sua felicidade e miséria".

No Cap. XI do Leviatã, que é complementado temática e conceitualmente pelo célebre Cap. XIII, Hobbes examina conceitos relativos à Moral, relacionando-a com a paz civil. Isso é evidente em sua definição dos costumes, os quais ele afirma que são "aquelas qualidades que dizem respeito a uma vida em comum pacífica e harmoniosa". Com essa definição, aparece mais uma vez a prioridade, em seu pensamento, da forma de se alcançar a paz civil, isto é, "a felicidade desta vida", a qual não consiste no "repouso de um espírito satisfeito", mas, sim, num "contínuo progresso do desejo" e na competição entre os homens.

Hobbes se opõe à concepção da existência de um fim último e de um bem supremo para o homem. Ele não cita filósofo algum ao afirmar isso, porém, é notório que a ideia de fim último é cara aos pensadores cristãos, especialmente a Santo Agostinho, que afirma que o homem foi feito para Deus e que não descansará a sua alma enquanto não se voltar para Deus, bem como que a pátria do cristão está nos céus, de onde se aguarda a vinda do Messias.

Quanto à afirmação do bem supremo ou Sumo Bem, é uma formulação própria de Platão, para quem o Bem é tanto a origem do ser quanto do conhecimento da verdade. Platão afirma que a Felicidade é desejada por todos os homens e que apenas na contemplação do bem se encontra a beatitude ou Felicidade perfeita.

No capítulo XI do Leviatã, Hobbes antecipa teses desenvolvidas no Cap. XIII, onde examina a condição de miséria da humanidade quando ainda não havia sido instituído o poder soberano. 


\section{AKEDIA}

O progresso do desejo do homem, citado por Hobbes, no Cap. XI, é explicado por Renato Janine Ribeiro, de forma comparativa em relação à marcha da própria vida, juízo comum na época da redação do Leviatã e presente na literatura religiosa inglesa, no livro $O$ Peregrino, que ilustrava a marcha do cristão em direção à beatitude, com todas as provações do percurso, o qual só os perseverantes conseguem completar.

A convicção de marcha ou progresso se dê em direção a algum bem desta vida, ou do porvir, era comum na mente dos ingleses do século XVII e, enquanto Bunyan concebe essa marcha rumo à vida eterna, Hobbes a limita aos desejos desta vida. Ele afirma como tese básica de sua Antropologia: "Assinalo assim, em primeiro lugar, como tendência geral de todos os homens, um perpétuo e irrequieto desejo de poder e mais poder, que cessa apenas com a morte" (Leviatã, Cap. XI).

Hobbes concebe a marcha do desejo do homem como algo infindável, pois o desejo se desloca de um objeto para outro, "não sendo a obtenção do primeiro outra coisa senão o caminho para se conseguir o segundo", de tal modo que, já no Cap. XI do Leviatã, o filósofo antecipa a imagem da confiança na segurança da sociedade pelo Estado, para que os homens possam levar uma vida quieta e sossegada, na qual possam desfrutar de seus desejos em paz, inclusive do desejo sensual.

No Cap. XIII do Leviatã, a igualdade dos seres humanos é concebida como natural, pois ali Hobbes afirma:

A natureza fez os homens tão iguais, quanto às faculdades do corpo e do espírito que, embora por vezes se encontre um homem manifestamente mais forte de corpo, ou de espírito mais vivo do que outro, mesmo assim, quando se considera tudo isto em conjunto, a diferença entre um e outro homem não é suficientemente considerável para que qualquer um possa com base nela reclamar qualquer benefício a que outro não possa também aspirar, tal como ele. Porque quanto à força corporal o mais fraco tem força suficiente para matar o mais forte, quer por secreta maquinação, quer aliando-se com outros que se encontrem ameaçados pelo mesmo perigo. Quanto às faculdades do espírito..., encontro entre os homens uma igualdade ainda maior do que a igualdade de força ${ }^{5}$.

\footnotetext{
${ }^{5}$ Thomas Hobbes. Leviatã, Cap. XIII. S. Paulo: Abril, 1979.
} 


\section{AKEDIA}

A partir dessa tese da igualdade natural ele refutará o argumento de que há homens mais fortes, ou mais sábios. Se há mais fortes, os mais fracos podem unir-se para vencê-los, ou o mais fraco, por intermédio de um secreto ardil, pode derrotar o mais forte.

Quanto à existência de homens mais sábios, Hobbes diz que há poucos verdadeiramente sábios, mas que a prudência, que é aprendida via experiência, é comum a todos os homens, o que demonstra a sua igualdade. Ironicamente o autor também diz que os homens são iguais em relação à presunção de serem mais sábios uns do que os outros, e a vaidade, assim, comuns a todos.

A igualdade natural dos homens, no entanto, não garante a vida em segurança e a Felicidade, pois quando dois homens desejarem a mesma coisa, sendo impossível sua fruição por ambos, instaurar-se-á a competição. E, nessa situação, as virtudes principais passarão a ser a fraude, e a antecipação, chegando os homens a uma situação em que, por não haver um poder comum, de onde possa derivar-se a Lei, nada poderá ser injusto. Essa é a condição de infelicidade e miséria na qual se encontrava o homem antes da criação do Estado, o qual foi projetado para a paz e a defesa da sociedade.

Em relação à afirmação de Hobbes, de que onde não há Lei nada pode ser injusto, é salutar observar que o apóstolo Paulo já dissera que: "onde não há Lei, também não há transgressão" (Rm, 4:15), bem como afirmou: "Eu não teria conhecido o pecado, senão por intermédio da Lei; pois não teria eu conhecido a cobiça, se a Lei não dissera: Não cobiçarás" (Rm, 7:7).

Logo, a imaginação de um estado de natureza e de um estado civil não era estranha a Paulo, observando-se que Paulo, ao escrever isso, estava se referindo aos aspectos civis da Lei, não aos aspectos teológicos. Nesse sentido, Hobbes chama a atenção para o fato de que, dentre os "Dez Mandamentos", os quatro primeiros dizem respeito aos deveres para com Deus e os outros seis à vida civil.

Foi em relação a esses que Paulo afirmou que não conheceria a cobiça se a Lei não dissesse: não cobiçarás. Logo, Paulo e Hobbes entendem que só haverá transgressão onde houver Lei. 


\section{AKEDIA}

Enquanto estão no estado de natureza, os homens têm um constante medo da morte violenta, não há lugar para a indústria, o comércio, a arte, a filosofia, "e a vida do homem é solitária, pobre, sórdida, embrutecida e curta". Diante disso, de acordo com Hobbes, a razão orienta os homens para normas de paz que garantirão o convívio em respeito e em prazer entre os homens, os quais, deixados no estado de natureza, são como lobos uns para os outros.

A contínua marcha do desejo, pois, leva os homens à criação daquele grande Leviatã, que é o Estado, ao qual prometem obediência, em troca da garantia da segurança e do gozo da vida, numa equação em que a razão serve ao desejo fundamental, que é o da vida em paz.

Assim, para Hobbes, a Felicidade está necessariamente ligada à vida em paz na sociedade, tanto dentro dos limites de cada Estado quanto nas relações exteriores, pois em tempos de guerra, a Felicidade do corpo político e dos indivíduos é limitada.

Dependendo das circunstâncias, os homens voltam ao estado de natureza, pois o realismo da guerra impede que os homens possam viver em si e para si, agora eles fazem parte do corpo político e estão sujeitos até a entregar o seu corpo por ele, para a libertação da sociedade. E, assim, a nossa paz e Felicidade social e política dependem do sacrifício dos nossos heróis e mártires da guerra.

Política e Felicidade são associadas também no pensamento de Locke, que afirma que "o legislador é a alma do corpo político, da qual todos os membros do Estado tiram o quanto Ihes é necessário à conservação, união e Felicidade".

Montesquieu via na Felicidade política o maior bem do homem, ao afirmar: "Se pudesse fazer com que todos pudessem melhor sentir sua Felicidade em cada país, em cada governo, acreditar-me-ia o mais feliz dos mortais".

Por seu turno, Rousseau afirmou: "Se tivera de escolher o lugar de meu nascimento, teria desejado nascer num país no qual o soberano e o povo não pudessem alimentar senão um único e mesmo interesse, a fim de que todos os movimentos da máquina tendessem somente para a Felicidade comum". 


\section{DIVERSOS CONTEXTOS DE USO E DE SIGNIFICAÇÃO DO TERMO FELICIDADE NA BÍBLIA}

O tema da Felicidade é abordado em diversos textos do "Antigo" e do "Novo Testamento", tanto de forma direta quanto de forma indireta, e mesmo de forma implícita, cabendo ao leitor perceber, no contexto da narrativa, as suas relações com a Felicidade.

A conquista de Canaã, por Josué, por exemplo, a fim de que o futuro povo de Israel pudesse se fixar nessa terra, se deu depois de ter saído da escravidão do Egito, mas, ainda assim, era vista pelos israelitas como mais um dos atos de cumprimento da promessa de Deus de uma terra em que manaria leite e mel e, portanto, de Felicidade.

Encontrar uma mulher virtuosa também era sinal de Felicidade no "Antigo Testamento", como diz o "Livro de Provérbios": "Mulher virtuosa, quem a achará? O seu valor muito excede o de finas joias" (Pv, 31.10). Ao mesmo tempo em que esse provérbio enaltece a mulher virtuosa, ele pode conter uma ironia às mulheres em geral, visto que ao dizer que é difícil encontrar uma mulher virtuosa, ao mesmo tempo em que elogia a virtuosa, desqualifica as demais. E, como ter uma fina joia, lato sensu, seria posse para poucos, o provérbio pode ter um sentido inverso, isto é, em lugar de elogiar a mulher, a desmerece.

Em Israel, o fato de dar à luz uma criança era sinal de Felicidade, como se vê no contraste entre as mulheres de Jacó, das quais uma, chamada Lia, disse que era afortunada, isto é, feliz, por ter vários filhos, enquanto sua irmã Raquel se sentia angustiada por não gerar filhos, vendo em Lia uma concorrente. E, atribuindo a geração de filhos ao homem, disse a seu marido: "Dá-me filhos, senão morrerei" (Gn, 30:1).

Jacó, porém, entendia que o fato dela não ter filhos provinha de Deus. Foi, então, que ela resolveu ceder sua serva Bila por mulher a Jacó, dizendo: "Eis aqui Bila, minha serva; coabita com ela, para que dê à luz, e eu traga filhos ao meu colo, por meio dela" (Gn, 30:3).

Diante disso, sua irmã Lia "tomou também a Zilpa, sua serva, e deu-a a Jacó, por mulher" (Gn, 30:9). E, quando nasceu a criança, Lia disse: "afortunada", expressando, assim, sua Felicidade diante da concorrência com 


\section{AKEDIA}

Raquel. Depois Zilpa, serva de Lia, teve ainda outro filho de Jacó, ocasião em que Lia disse: "É a minha felicidade, porque as filhas me terão por venturosa" (Gn, 30:13).

A Felicidade pode ser encontrada, portanto, em situações de disputa como essa, na qual as irmãs tinham uma concorrência tamanha que, mesmo considerando-se que naquela sociedade a poligamia era um costume, ainda que tivessem ciúmes de suas servas, viam-nas como instrumentos de sua concorrência. E, assim, Bila e Zilpa foram mães, mas os filhos eram das suas senhoras, que continuaram competindo até que Raquel, tendo dado à luz a Benjamin, morreu. Raquel, desde então, se tornou um símbolo da mulher que encontra a Felicidade na maternidade.

Uma situação de profunda dor e infelicidade é narrada no "Livro de Rute". Depois de sair de Israel e dirigir-se a Moabe, a fim de procurar sustento, ali morreram seu marido e seus dois filhos. Então, ela voltou para Israel com sua nora Rute. Seus amigos e conhecidos a chamaram pelo seu nome, Noemi, que significa "agradável, amável, prazeroso". Porém, ela Ihes pediu que não a chamassem mais por esse nome, visto que grande amargura the havia dado 0 Todo-Poderoso. Adotou, então, o nome de Mara, cujo significado é "amarga" ou "amargo" . Sua profunda experiência de perda mostra que a Felicidade pode se relacionar diretamente com a posse dos bens necessários para 0 sustento e com a preservação da vida dos entes queridos.

Por outro lado, a posse dos mais diversos bens, a sabedoria e mesmo a abundância de mulheres, como ocorreu com Salomão, não é garantia de Felicidade. "Tinha ele setecentas mulheres, princesas, e trezentas concubinas; e suas mulheres Ihe perverteram o coração" (I Rs, 11:3). Ele mesmo escreveu, de acordo com a "Versão Almeida Revista e Atualizada": "Amontoei também para mim prata e ouro e tesouros de reis e de províncias; provi-me de cantores e cantoras e das delícias dos filhos dos homens: mulheres e mulheres" (Ec, 2:8).

A Bíblia Ave Maria traduz esse evento de forma semelhante, porém, mais contundente ao se referir às mulheres: "Acumulei também prata e ouro,

\footnotetext{
${ }^{6} \mathrm{O}$ termo "Mara" é usado também no Livro do Êxodo para descrever as águas amargas, não potáveis.
} 


\section{AKED』A}

riquezas de reis e de províncias. Arranjei cantores e cantoras, e o que faz as delícias dos filhos dos homens: mulheres e mulheres".

No fim das contas, porém, isso não fez de Salomão um homem feliz, e notável é o pessimismo de Salomão, apesar de homem de ciência e de sabedoria, riquíssimo e politicamente forte, dentro e fora de Israel. Chegou à conclusão, porém, de que "tudo é vaidade". Sua biografia mostra, por sua vez, que a sabedoria, a riqueza, o poder e o prestígio não são suficientes para se alcançar a Felicidade.

A simplicidade de Cristo, no entanto, poderia nos aproximar muito mais da Felicidade: "Considerai como crescem os lírios do campo: eles não trabalham, nem fiam. Eu, contudo, vos afirmo que nem Salomão, em toda a sua glória, se vestiu como qualquer deles" (Mt, 6: 28-29). É como disse Voltaire: a Felicidade é inferior à bem-aventurança.

Por outro lado, que a força não seja suficiente para que um homem possa alcançar a Felicidade ficou demonstrado pela vida de Sansão, que foi vencido pelos Filisteus, vitimado pela força da sedução de uma mulher e, assim, o homem que ceifou a vida de um leão com as mãos, que matara mais de mil homens usando como arma a queixada de um jumento (Jz, 15: 15-16), e que carregara o portão da cidade de Gaza, nas costas, não foi capaz de resistir à seiva de uma mulher. Foi vencido, portanto, por meio de uma estratégia simples: se não o venceram pela força, venceram-no por sua própria fraqueza. E, assim, Sansão dormiu nos braços de Dalila, teve seus cabelos cortados, perdeu a eficácia da coragem, pois o voto do nazireado, isto é, da sua consagração a Deus, desde o seu nascimento, fora quebrado.

Passado algum tempo, no entanto, Sansão recuperou a sua força e, derrubando o templo de Dagom, que era tanto um local religioso quanto político, matou 3.000 filisteus, dando também a própria vida em sacrifício pela libertação de seu povo. Conseguiu derrubar um templo, mas não teve ímpeto suficiente diante da sedução de uma mulher, sinal de que a fraqueza da carne pode ser superior à fortaleza do corpo, o que não nos torna felizes.

Por outro lado, no antigo Israel, o conceito de Felicidade entrou em crise, devido à corrupção dos próprios sacerdotes. É possível que hoje venhamos a concordar com o profeta Malaquias, que afirmou: "Nós reputamos por felizes os 


\section{AKED』A}

soberbos; também os que cometem impiedade prosperam, sim, eles tentam ao Senhor e escapam" (Ml, 1:15). E isso ele denunciava em torno de 430 a. C.

No Brasil, por outro lado, talvez pareça que Rui Barbosa fez uma releitura de Malaquias, visto que afirmou: "De tanto ver triunfar as nulidades; de tanto ver prosperar a desonra, de tanto ver crescer a injustiça. De tanto ver agigantarem-se os poderes nas mãos dos maus, o homem chega a desanimarse da virtude, a rir-se da honra e a ter vergonha de ser honesto" ${ }^{\text {"7 }}$. Isso foi dito, em 1914, porém, até hoje continua sendo uma realidade.

Por fim, numa contradição evidente aos padrões vigentes historicamente, Cristo considerou como pessoas felizes os humildes de espírito, os que choram, os mansos, os que têm fome e sede de justiça, os misericordiosos, os limpos de coração, os pacificadores, os perseguidos por causa da justiça e os que são injuriados, perseguidos e caluniados por serem seus seguidores.

É digno de nota também que, enquanto o "Livro de Mateus" se refere, nas bem-aventuranças, aos que têm fome e sede de justiça, o "Livro de Lucas" fala apenas dos que têm fome. Porém, mesmo que o evangelista Lucas não se refira à fome de justiça, a fome está diretamente relacionada à injustiça, devido à exploração dos trabalhadores, à concentração da propriedade e da renda, à corrupção política e a outras formas de injustiça, o que foi denunciado na "Epístola de Tiago": "Porventura não são os ricos os que vos oprimem e os que vos arrastam aos tribunais? Não blasfemam eles o bom nome pelo qual sois chamados?" (Tg, 2:6).

\section{O TEMA DA FELICIDADE NA MÚSICA BRASILEIRA}

A Felicidade é tema também da poesia e da música brasileira, seja na variante popular ou na modalidade sertaneja, das quais destacamos inicialmente a renomada música Felicidade, de Lupicínio Rodrigues, que se tornou conhecida também na voz de Caetano Veloso:

Obras Completas de Rui Barbosa - Discursos Parlamentares. Disponível em: http://www.stf.jus.br/bibliotecadigital/RuiBarbosa/16040_V41_T2/PDF/16040_V41_T2.pdf . Acesso em: $21 / 03 / 2021$ 
Felicidade foi-se embora

E a saudade no meu peito ainda mora

E é por isso que eu gosto lá de fora

Porque sei que a falsidade não vigora

A minha casa fica lá de traz do mundo

Onde eu vou em um segundo quando começo a cantar

O pensamento parece uma coisa à toa

Mas como é que a gente voa quando começa a pensar

Trata-se de um texto breve e nostálgico, que afirma que a Felicidade está ausente. A expressão "a minha casa fica lá de trás do mundo" é uma negação da Felicidade, como se o poeta se referisse ao não-ser. O eu-lírico não define, porém, o que seja a Felicidade, mas usa um termo de uso comum e cuja definição é subjetiva e relativa. Dessa forma, o autor iniciou um hipertexto, o qual é complementado de acordo com a experiência e o sentimento de cada um que lê, ouve e canta essa letra tão breve, porém, essencial para descrever um sentimento que atinge a grande parte da humanidade. Por outro lado, ao dizer: "É por isso que eu gosto lá de fora porque sei que a falsidade não vigora", reconhece que a verdade nas relações humanas é um fator fundamental para a felicidade.

Uma visão imediatista e pessimista da Felicidade aparece na canção de Odair José, intitulada $A$ noite mais linda do mundo, cujo refrão é: "felicidade não existe, o que existe na vida são momentos felizes", ficando, assim, a noção de Felicidade do autor reduzida a uma noite ou a um breve período de amor:

A noite mais linda do mundo (A Felicidade)

Vamos fazer desta noite

A noite mais linda do mundo

Vamos fazer nesta noite

A vida inteira num segundo

A gente pode ser feliz

Viver a vida sem sofrer

É não pensar no que vai ser

Não me pergunte se amanhã

O nosso amor vai existir

Não me pergunte pois não sei

Refrão: Felicidade não existe

O que existe na vida são momentos felizes ${ }^{8}$

\footnotetext{
${ }^{8}$ Disponível em: https://www.letras.mus.br/otto/a-noite-mais-linda-do-mundo/. Acesso em: 03/04/2021.
} 


\section{AKEDTA}

Outro exemplo de pessimismo em relação à Felicidade está na música No Colo da Noite, gravada, dentre outros, por Milionário e José Rico, que diz:

Cansado de tanto esperar a felicidade

Saí à sua procura no mundo sem fim.

Tão depressa eu me deparei com a realidade.

Vi que ela existe para todos, menos para mim.

Os amores que tive na vida todos me deixaram Juramentos e mais juramentos fizeram em vão Somente as tristes lembranças comigo ficaram E dos beijos fingidos agora só recordação

Caminhos e rumos incertos, sozinho eu sigo

Não tenho esperança de nada pra levar comigo

O dia é meu companheiro, clareia o caminho

No colo da noite adormeço, chorando sozinho

O problema dessa visão da Felicidade é a sua centralização na outra pessoa, como se, sem ela, fosse impossível ser feliz. O sujeito moral, porém, deve procurar ser feliz, não só no que tange ao relacionamento amoroso, mas, também, por encontrar uma forma de ser feliz por si mesmo.

Nesse sentido, nos é pertinente parafrasear Kant, que afirmou: "Tem coragem de servir-te de teu próprio entendimento", poderíamos dizer: "Tem coragem de ser feliz por ti mesmo".

Outra forma de interpretação da Felicidade é a que consiste em considerar o passado como tendo sido mais feliz do que o presente, especialmente para os que migraram do interior para os grandes centros urbanos, ou mesmo para uma cidade de pequeno porte. Isso fica evidente no maior sucesso da dupla sertaneja Belmonte e Amaraí, na canção Saudade da minha terra, texto em que o poeta coloca uma questão existencial profunda: "De que me adianta viver na cidade se a felicidade não me acompanhar?".

$\mathrm{E}$, partindo desse mote, o sertanejo representado na música coloca argumentos e sentimentos que justificariam seu retorno ao campo. Nem uma mulher da cidade que se interessou por ele o seguraria na metrópole. Ele é um caipira do asfalto que chora a saudade do campo, vive sem alegria na cidade, cansou-se de sofrer e precisa voltar para o lugar onde nasceu e onde quer morrer. A Felicidade só estaria na terra, e na terra natal.

O campo é como um ímã para as pessoas que ali foram criadas. Elas se lembram do orvalho, do canto dos pássaros, do mugido das vacas, do som das 


\section{AKED』A}

rodas dos carros de boi, da solidariedade dos vizinhos, das festas na roça etc. No entanto, essa nostalgia vai contra a lógica da produção capitalista, que exige uma adaptação às novas tecnologias, as quais reduziram a oferta de emprego no campo e aumentaram o êxodo rural.

Ao contrário dessa nostalgia em relação à terra, Domenico De Masi afirma que "quando, em plena era industrial, os nossos avós - ainda rurais falavam de trabalho, suas mentes corriam aos campos e camponeses, ainda que a maioria dos trabalhadores braçais agrícolas já estivesse abandonando 0 campo para se urbanizar e trabalhar em fábricas"9.

Diante disso não faria sentido perguntar: "De que me adianta viver na cidade se a felicidade não me acompanhar?". Ao contrário, chegou há anos, o tempo da necessidade de desenvolvermos a capacidade da adaptação e da atualização das nossas competências, não só as profissionais, mas, também, e talvez em maior escala, das emocionais.

O amor pelo campo levou Catulo da Paixão Cearense a compor o poema-canção Luar do Sertão:

Ó que saudade do luar da minha terra

Lá na terra branquejando folhas secas pelo chão

Este luar cá da cidade tão escuro

Não tem aquela saudade do luar do meu sertão

Não há, ó gente, oh! não

Luar como esse do sertão

Se confrontarmos essa música, no entanto, com os sofrimentos do sertanejo, assim como descritos por Jorge Amado, na obra Seara Vermelha, em que veremos que o sertão foi um lugar de exploração e de outras formas de violência contra os trabalhadores. Para denunciar isso foi que Jorge Amado, já na abertura da obra, cita Castro Alves:

Cai, orvalho de sangue do escravo

Cai, orvalho na face do algoz

Cresce, cresce, seara vermelha

Cresce, cresce, vingança feroz.

Para Jorge Amado, o vermelho, ao qual Castro Alves se referia, era o sangue do trabalhador derramado na Seara, isto é, na colheita, a qual trazia consigo as marcas da exploração do homem do campo.

\footnotetext{
${ }^{9}$ Domenico De Masi. O Futuro do Trabalho: fadiga e ócio na sociedade pós-industrial, p. 49.
} 
Por outro lado, o otimismo e a nostalgia em relação ao sertão são negados pelas descrições feitas por Euclides da Cunha (1984), na parte da obra Os Sertões, intitulada "A Terra".

De acordo com a sua descrição primorosa, há locais no sertão que são "barbaramente estéreis" e que "na plenitude das secas são positivamente o deserto". Dialeticamente, porém, chega um tempo em que "dilatam-se os horizontes. O firmamento, sem o azul carregado dos desertos, alteia-se, mais profundo, ante o expandir revivescente da terra. E o sertão é um vale fértil. É um pomar vastíssimo, sem dono"10. Porém, "depois tudo isto se acaba. Voltam os dias torturantes; a atmosfera asfixiadora; o empedramento do solo; a nudez da flora; e nas ocasiões em que os estios se ligam sem a intermitência das chuvas - o espasmo assombrador da seca. A natureza compraz-se em um jogo de antíteses"11.

Por isso, enfim, afirma Euclides que "o sertanejo é antes de tudo um forte"12. Porém, milhões deles migraram para o Sudeste e o Sul em busca de melhores condições de vida, o que reforça a posição de sua fortaleza, bem como o fato de que a Felicidade deve ser buscada, construída por nós.

\section{A FELICIDADE E A EMANCIPAÇÃO DA MULHER EM GABRIELA, CRAVO E CANELA}

Relevantes referências à Felicidade são feitas na obra Gabriela, Cravo e Canela, de Jorge Amado, publicada em 1958. Um dos conceitos mais importantes da obra em relação à Felicidade aparece numa referência ao Professor Josué, sobre quem várias pessoas de llhéus diziam que se interessara pela jovem Malvina para, por intermédio do casamento, enriquecerse facilmente, devido às posses do Coronel Melk Tavares, pai da jovem. É nesse contexto da narrativa, que o autor introduz a afirmação de que "casamento de dinheiro não traz felicidade".

\footnotetext{
${ }^{10}$ Euclides da Cunha. Os Sertões (1901), op. cit., p. 22.

Euclides da Cunha. Os Sertões (1901), p. 23. Disponível em: http://www.dominiopublico.gov.br/download/texto/bn000153.pdf. Acesso em: 03/04/2021.

${ }^{12}$ Ao descrever assim o sertanejo, no entanto, Euclides da Cunha acrescenta, de forma preconceituosa, que o sertanejo "não tem o raquitismo exaustivo dos mestiços neurastênicos do litoral". Os Sertões. Cap. III. Disponível em: http://www.nilc.icmc.usp.br/nilc/literatura/ossert.es2.htm. Acesso em: 03/04/2021.
} 


\section{AKED』A}

Jorge Amado usa os termos "infelicidade" e "desgraça" como sinônimos de violência e mesmo de morte em llhéus. Por exemplo, quando afirma, em relação a Anabela, uma dançarina que fazia danças ousadas e que foi para a cidade apresentar-se no Bataclan, famoso cabaré da cidade. A certa altura da história, devido ao conservadorismo da cidade, o narrador afirma que "no caso de the ocorrer uma infelicidade qualquer nessa terra assustadora, de costumes brutais", era com o Dr. Mundinho Falcão, exportador de cacau que a levou para a cidade, que ela poderia contar. Infelicidade, nesse contexto, significava violência, algumas vezes praticadas a mando das esposas dos coronéis, contra mulheres que poderiam ameaçar o seu casamento.

Ilhéus era uma cidade de costumes tão conservadores que os votos de Felicidade para um inimigo político deviam ser feitos de maneira estratégica. Foi o que fez Mundinho ao mandar flores para Jerusa, neta do Coronel Ramiro, intendente da cidade, com a seguinte mensagem: "Peço-lhe, minha jovem amiga, transmitir a seu digno avô meus votos de felicidade. Em campo oposto ao dele, sou, no entanto, seu admirador". O Coronel reconheceu tal forma de comunicação como uma estratégia sagaz do adversário, dizendo: "É sabido esse senhor Mundinho! Se me manda o abraço por minha neta, não posso deixar de receber".

Outra referência à Felicidade na obra está presente na descrição do comportamento do Juiz de Paz que, tendo demonstrado anteriormente interesse por Gabriela, constrangido ao celebrar o casamento dela com Nacib, "pronunciou umas palavras para desejar felicidades àquele novo casal, que um amor verdadeiro unira acima das convenções sociais, das diferenças de posição e classe".

O uso do termo "felicidades", em Gabriela (1958), indica que esse substantivo, que em geral é usado no singular, pode ser aplicado também no plural, mesmo que a gramática o reprove, pois, de acordo com Wittgenstein, o significado das palavras está para além da gramática, devendo ser buscado no uso que delas se faz. Ao grafar "felicidades", portanto, o autor indica que a Felicidade tem várias formas de se apresentar ${ }^{13}$.

\footnotetext{
${ }^{13}$ Na novela Felicidade, de Manoel Carlos, o prefeito de Vila Feliz se alegra quando sua mulher tem o décimo filho. Pode haver felicidade maior? Louvado seja Deus!, diz ele. Compra charutos para os amigos. Um funcionário da Prefeitura diz: "Está alegre como se fosse solteiro". Para este, a felicidade estaria fora
} 
O romance de Nacib e Gabriela teve aspectos de Felicidade e de infelicidade. Casando-se com Gabriela, ele sentiu-se muito feliz. No entanto, devido ao envolvimento de Gabriela com Tonico Bastos, escrivão da cidade, Nacib sentiu-se muito infeliz, vindo depois a perdoá-la e a recuperar a Felicidade ao seu lado. É a dialética apontada por Voltaire, sobre a transitoriedade da Felicidade. Por outro lado, Jorge Amado introduz na obra o enredo a respeito do Doutor Felismino, um dentista que se sentiu feliz por abandonar sua mulher, que havia sido infiel. Ele encontrou na infidelidade da mulher uma justificativa para deixá-la, visto que a considerava como uma pessoa insuportável.

No entanto, sua atitude não agradou à sociedade ilheense, cuja moral não admitia que um marido traído reagisse de forma pacífica diante da infidelidade do cônjuge. E, assim, sentindo-se rejeitado por seus concidadãos, teve de se mudar de llhéus. Jorge Amado até afirma, ao narrar que o Coronel Jesuíno Mendonça matara sua esposa, Sinhazinha Mendonça, juntamente com seu amante, que "assim era em llhéus: honra de marido enganado só com sangue podia ser lavada".

É digno de nota que a obra Gabriela (1958) tem como um dos temas centrais a denúncia da situação da mulher na sociedade de então. A mulher não tinha autonomia moral mesmo para escolher com quem iria se casar, pois devido aos interesses políticos e econômicos, alguns casamentos eram arranjados, a fim de se manter o domínio das famílias mais influentes.

A discussão sobre a emancipação da mulher recebe, assim, uma grande contribuição de Jorge Amado, não só em Gabriela (1958), mas, também, em Tereza Batista, cansada de guerra que estava. Ao todo, as expressões "mulher" e "mulheres" são usadas 324 vezes na obra Gabriela (1958), das quais destacamos as seguintes, com a finalidade de demonstrar como a mulher era desrespeitada na llhéus, de 1925:

- Mulher é para viver dentro de casa, cuidando dos filhos e do lar.

- Mulher casada é para viver no lar, criar os filhos, cuidar do esposo e da família.

- O lar é a fortaleza da mulher virtuosa.

do casamento, pois ele tinha um relacionamento conjugal infeliz. Assim, as concepções de felicidade são variáveis, de acordo com as circunstâncias históricas e pessoais. 


\section{AKED』A}

- Mulher tem muita serventia, o senhor nem imagina. Ajuda até na política. Dá filho p'ra gente, impõe respeito. Pro resto, tem as raparigas.

-Toda mulher, mesmo a mais fiel, tem seu limite.

- És a mulher desta casa, o raio de sol, a luz do luar, o canto dos pássaros.

- Cabeça de mulher é fraca.

- Mulher que se mete a doutora é mulher descarada, que quer se perder (Coronel Melk Tavares falando a Malvina, sua filha, que intentava continuar sua formação após concluir o Colégio).

Uma das expressões mais preconceituosas em relação à mulher, porém, é esta: "Mulher é tentação, é o diabo, vira gente", a qual faz parte de um diálogo entre três homens logo após o assassinato de Sinhazinha Mendonça e de seu amante, o Dr. Osmundo Pimentel. Na novela "Gabriela", de 1975, porém, a frase acima é alterada por Walter Durst, para: "Mulher é o diabo, vira a cabeça da gente".

De todo modo, em ambas as conceituações a mulher é a única responsabilizada pelo adultério ocorrido entre Sinhazinha Mendonça e Dr. Osmundo, ambos os quais foram mortos pelo Coronel Jesuíno Guedes Mendonça, cujo casamento com Sinhazinha fora arranjado para preservar as propriedades de suas famílias, que eram aparentadas. É em relação a isso que Jesuíno afirmava que todo casamento era político, especialmente para os grandes proprietários de terra e para as autoridades.

Nesse contexto político e cultural, o conceito de Felicidade, nos termos em que nos propomos aqui, nem poderia ser discutido. Nesse sentido, na versão de Gabriela (1958) para a televisão, em 1975, o Coronel Jesuíno Mendonça afirma que "fora da ligação política o casamento pode ser muito bom por algum tempo, mas depois acaba sempre dando muito trabalho"14.

Diante desse contexto moral, a obra de Jorge Amado é de alto valor, pois tem a emancipação da mulher como um dos temas principais. A personagem Gabriela é como se fosse o perfume da obra, porém, a sua essência é outra.

Grande parte dos espectadores da novela exibida em 1975, privilegiando o sensível em lugar do inteligível, dava maior valor à cena de Gabriela sobre o telhado de um coreto, em busca da pipa de uma criança, do que às denúncias presentes na obra sobre as várias formas da violência e da exclusão na

14 Gabriela, 1975, Cap. 25. Dir. de Walter Durst. Disponível em: https://www.youtube.com/watch?v=KLPYmKyKkzM. Acesso em: 08/04/2021. 


\section{AKED包}

sociedade, de forma especial em relação às mulheres. Aquele público que aparece na cena representa a sensualidade do homem brasileiro ${ }^{15}$.

Do ponto de vista da Política, porém, o objetivo da obra é o fim do Coronelismo e o predomínio do Direito no lugar da força, algo que Rousseau defendera sobejamente n'O Contrato Social. Assim, a Felicidade na obra Gabriela (1958) pode ser vista tanto do ponto de vista do indivíduo, especialmente em relação à autonomia da mulher, especialmente em personagens como Sinhazinha Mendonça, mencionada logo na primeira página da obra, Malvina e Gabriela, que nasceu assim, cresceu assim, vai ser sempre assim - livre - como sintetizou Caymmi na Modinha para Grabriela. É uma obra que trata, portanto, da Felicidade política e da Felicidade do indivíduo: uma preciosa utopia amadiana.

\section{CONSIDERAÇÕES FINAIS}

Conforme verificamos, as noções e as experiências da Felicidade são muito amplas e variáveis. Para muitos a felicidade estaria em conseguir encontrar a pessoa amada. Para outros, no entanto, em sair de um relacionamento infeliz.

A maioria associa a Felicidade ao sustento, ao emprego, à propriedade, à moradia, ao estudo, à saúde, e mesmo comprar uma roupinha nova de vez em quando não faria mal a ninguém, bem como dar um retoque no visual.

Muitos, porém, ficariam felizes por um prato de comida, como se vê nas grandes cidades do mundo e mesmo em cidades do interior do Brasil, o que nos leva a pensar a Felicidade também e necessariamente do ponto de vista da Economia, da Política e da Solidariedade entre os cidadãos.

O Capitalismo, porém, adota uma lógica econômica que não preza as pessoas, mas, sim, o lucro. Dessa forma, a definição hobbesiana do homem como lobo do homem ainda é atual, e o Estado, criado com o objetivo de garantir a paz da sociedade, em determinadas circunstâncias, tem se voltado contra ela, pois ele não é apenas uma pessoa fictícia, mas é formado por homens e mulheres que têm vontade e interesses próprios, e seu objetivo de

15 Parte da cena encontra-se disponível em (https://globoplay.globo.com/v/1257554/). O personagem Tonico Bastos (Fúlvio Stefanini), de chapéu, sintetiza a sensualidade dos homens da cidade na cena. 


\section{AKED』A}

alcançar a salus populi (segurança pública) não se concretizou, pois os atores políticos se preocupam mais, salvo raras exceções, com a sua própria carreira, e o desejo de poder e mais poder, como disse o próprio Hobbes, especialmente para eles, só cessa com a morte.

Enfim, quando falamos da Felicidade tratamos de experiências e de conceitos variáveis, relativos e subjetivos, tanto que "a alma farta pisa o favo de mel, mas, para o faminto, todo amargo é doce", pelo que a Felicidade se relaciona diretamente com a nossa subjetividade. Sendo assim, não há uma forma geral e definitiva para sermos felizes, todavia, é oportuno que recordemos as palavras de Marx: "A sociedade poderá inscrever na sua bandeira: de cada um segundo suas capacidades, a cada um segundo suas necessidades" ${ }^{\prime 16}$.

Teríamos, então, a Felicidade social, que, noutra forma de dizer: "Amarás o teu próximo como a ti mesmo" (Lv, 19:18), princípio este que não foi enunciado pela primeira vez por Jesus, mas faz parte da Torah, sendo citado por sete vezes, nos textos do "Novo Testamento"17. Contudo, o individualismo tem levado até mesmo cristãos a repetirem o slogan de que "não existe almoço de graça", mesmo que os "Evangelhos" registrem duas multiplicações dos pães, o que nos leva a concluir lembrando-nos que René Descartes afirmou:

O bom senso é a coisa mais bem distribuída do mundo... O poder de bem julgar e de distinguir o verdadeiro do falso, que é propriamente o que se denomina bom senso ou razão, é por natureza igual em todos os homens... Não basta ter o espírito bom, mas o principal é aplica-lo bem. As maiores almas são capazes dos maiores vícios, assim como das maiores virtudes"18.

Sendo, pois, o bom senso, assim tão bem distribuído, cabe a nós colocálo em prática. A unanimidade é impossível, entretanto, a razoabilidade é sempre tangível.

16 Manual de Economia Política. Academia de Ciências da URSS. Disponível em: https://www.marxists.org/portugues/ostrovitianov/1959/manual/35.htm. Acesso em: 03/01/2021.

${ }^{17}$ Confira em Mt, 19.19; Mt, 22.39; Mc, 12;31; Lc, 10.27; Rm, 13.9; Gl, 5.14 e Tg, 2.8.

${ }^{18}$ René Descartes. Discurso do Método. Trad. de Maria E. Galvão. S. Paulo: Martins Fontes, 2001, p. 05. 


\section{REFERÊNCIAS}

AMADO, Jorge. Gabriela, Cravo e Canela. Crônica de uma cidade do interior. 23. ed. S. Paulo: Martins, 1961.

AMADO, Jorge. Seara Vermelha. 32. ed. Rio de Janeiro: 1978.

AMADO, Jorge. O Gato Malhado e a Andorinha Sinhá. 43. ed. Rio: Record, 2004.

BOBBIO, Norberto. A Teoria das Formas de Governo. 4. ed. Brasília: Ed. UNB, 1985.

CUNHA, Euclides da. Os Sertões. São Paulo: Editora Três, 1984 (Biblioteca do Estudante). Disponível em: http://www.dominiopublico.gov.br/download/texto/bv000091.pdf. Acesso em: 08/04/2021, às 20h41min.

DE MASI, Domenico. O Futuro do Trabalho: fadiga e ócio na sociedade pósindustrial.

DESCARTES, René. Discurso do Método. S. Paulo: Martins Fontes, 2001.

HOBBES, Thomas. Do Cidadão. S. Paulo: Martins Fontes, 1992.

HOBBES, Thomas. Leviatã. 2. ed. S. Paulo: Abril, 1979.

MONTESQUIEU, Charles L. de Secondat. Do Espírito das Leis. S. Paulo: Abril, 1973.

KANT, Immanuel. Resposta à pergunta: o que é esclarecimento? Petrópolis: Vozes, 1985

LEOPOLDO E SILVA, Franklin. Felicidade. Dos filósofos pré-socráticos aos contemporâneos. São Paulo: Claridade, 2007.

LOCKE, John. Segundo Tratado sobre o Governo. S. Paulo. Abril, 1973.

ROMEIRO, Adriana. Os sertões da fome: História trágica das minas de ouro em fins do século XVII. SÆculum - Revista de História; João Pessoa, jul./ dez. 2008, p. 176.

ROUSSEAU, Jean-Jacques. Do Contrato Social. S. Paulo. Abril, 1978.

ROTHSTEIN, Andrew (Ed). Manual de Economia Política - Academia de Ciências da URSS. Disponível em: https://www.marxists.org/portugues/ostrovitianov/1959/manual/35.htm. Acesso em 08/04/2021, às 20h53min.

SALLAH, Jacques. A Bahia de Jorge Amado. Salvador: Fundação Casa de Jorge Amado, 2008 (Casa de Palavras).

STRONG, James. Strong's Exhaustive Concordance. Disponível em: https://biblehub.com/strongs.htm. Acesso em 08/04/2021, às 20h56min.

VOLTAIRE, François-Marie. Dictionnaire Philosophique - Heur. Disponível em: https://www.voltaire-integral.com/?s=Heur. Acesso em 08/04/2021, às 20 h51min. 


\section{AKED芭A}

\section{VERSÕES DA BÍBLIA UTILIZADAS}

1 - Bíblia Almeida, Revista e Atualizada

(https://www.bibliaonline.com.br/ara/gn/1)

2 - Bíblia Almeida, Revista e Corrigida

(https://www.bibliaonline.com.br/arc/gn/1)

3 - Bíblia Ave Maria (https://www.bibliacatolica.com.br/biblia-avemaria/genesis/1/)

4 - The Authorized King James Version of 1611. Salt Lake City, USA: The Church of Jesus Christ of Latter-Days Saints, 1979.

\section{SITES CONSULTADOS}

https://biblehub.com/

https://www.letras.mus.br

http://www.nilc.icmc.usp.br/nilc/literatura/ossert.es2.htm

http://www.stf.jus.br/bibliotecadigital/RuiBarbosa/16040 